\title{
Bioconjugated Gold Nanodots and Nanoparticles for Protein Assays Based on Photoluminescence Quenching
}

\author{
Chih-Ching Huang, Cheng-Kang Chiang, Zong-Hong Lin, Kun-Hong Lee, and Huan-Tsung Chang* \\ Department of Chemistry, National Taiwan University, 1, Section 4, Roosevelt Road, Taipei 106, Taiwan
}

This study describes the first instance of the use of two differently sized Au nanoparticles (Au NPs), acting separately as donor and acceptor, in homogeneous photoluminescence quenching assays developed for the analysis of proteins. Introduction of a breast cancer marker protein, platelet-derived growth factor AA (PDGF AA), to a solution of 11-mercaptoundecanoic acid-protected, 2.0$\mathrm{nm}$ photoluminescent $\mathrm{Au}$ nanodots $\left(\mathrm{L}_{\mathrm{AuND}}\right)$ led to the preparation of PDGF $\mathrm{AA}-\mathrm{L}_{\mathrm{AuND}}$ as the donor. Thiolderivative PDGF binding aptamers (Apt) and 13-nm spherical Au NPs were used to synthesize the Apt $-Q_{A u N P}$ acceptor. The photoluminescence of PDGF AA- $\mathrm{L}_{\mathrm{AuND}}$ at $520 \mathrm{~nm}$ decreased when photoluminescence quenching occurred between Apt $-\mathbf{Q}_{\text {AuNP }}$ and PDGF AA- $\mathbf{L}_{\text {AuND }}$. We used the PDGF AA- $\mathbf{L}_{\mathrm{AuND}} / \mathrm{Apt}-\mathbf{Q}_{\mathrm{AuNP}}$-based molecular light switching system to analyze PDGFs and PDGF $\alpha$-receptor in separate homogeneous solutions. In the presence of PDGFs, the interaction between Apt- $\mathbf{Q}_{\text {AuNP }}$ and $P D G F A A-L_{A u N D}$ decreased as a result of competitive reactions between the PDGFs and $\mathrm{Apt}-\mathbf{Q}_{\mathrm{AuNP}}$. Similarly, the interaction between $\mathrm{Apt}-\mathrm{Q}_{\mathrm{AuNP}}$ and PDGF AA- $\mathrm{L}_{\mathrm{AuND}}$ reduced as a result of competitive reactions between PDGF $\alpha$-receptor and PDGF AA- $\mathrm{L}_{\mathrm{AuND}}$. The limits of detection (LODs) for PDGF AA and PDGF $\alpha$-receptor were $80 \mathrm{pM}$ and $0.25 \mathrm{nM}$, respectively, resulting from a low background photoluminescence signal. When using the Apt- $Q_{\text {AuNP }}$ as selectors for (a) the enrichment of PDGF $\mathrm{AA}$ and (b) the removal of matrixes possessing intense background fluorescence from cell media and urine samples, the LOD for PDGF AA decreased to $10 \mathrm{pM}$. Unlike quantum dots, the $L_{A u N D}$ provide the advantages of biocompatibility, ease of bioconjugation, and minimal toxicity.

The application of photoluminescence quenching is a powerful technique for protein analysis. ${ }^{1}$ Intermolecular and intramolecular photoluminescence quenching between the donor and acceptor through specific binding of fluorophore-labeled probes toward

* To whom correspondence should be addressed. Phone and fax: 011-8862-33661171. E-mail: changht@ntu.edu.tw.

(1) (a) Li, I.; Pham, E.; Truong, K. Biotechnol. Lett. 2006, 28, 1971-1982. (b) Mátyus, L.; Szöllösi, J.; Jenei, A. J. Photochem. Photobiol. 2006, 83, 223236. (c) Giepmans, B. N. G.; Adams, S. R.; Ellisman, M. H.; Tsien, R. Y. Science 2006, 312, 217-224. (d) Schuler, B. ChemPhysChem 2005, 6, 1206-1220.

10.1021/ac701998f CCC: $\$ 40.75$ (C) 2008 American Chemical Society Published on Web 02/01/2008 target analytes is sensitive and of interest. ${ }^{2}$ One interesting example is the use of fluorophore-labeled aptamers for the analysis of proteins such as platelet-derived growth factor (PDGF), ${ }^{2 g, h}$ which was associated with a variety of disorders, including atherosclerosis; fibroproliferative diseases of lungs, kidneys, and joints; and neoplasia. ${ }^{3}$ The PDGF also found is an important protein for cell transformation and tumor growth and progression. ${ }^{4}$ Aptamers are advantageous over antibodies because they can be engineered, are more easily labeled with signal moieties such as fluorophores and enzymes, are more stable, and are of a relatively lower cost. ${ }^{5-7}$ When using fluorophore-labeled aptamers, tedious

(2) (a) Piston, D. W.; Kremers, G.-J. Trends Biochem. Sci. 2007, 32, 407-414. (b) Juskowiak, B. Anal. Chim. Acta 2006, 568, 171-180. (c) Michalet, X.; Kapanidis, A. N.; Laurence, T.; Pinaud, F.; Doose, S.; Pflughoefft, M.; Weiss, S. Annu. Rev. Biophys. Biomol. Struct. 2003, 32, 161-182. (d) Clapp, A. R. Medintz, I. L.; Mattoussi, H. ChemPhysChem 2006, 7, 47-57. (e) Pfleger, K. D. G.; Eidne, K. A. Nat. Methods 2006, 3, 165-174. (f) Heyduk, E.; Heyduk, T. Anal. Chem. 2005, 77, 1147-1156. (g) Vicens, M. C.; Sen, A.; Vanderlaan, A.; Drake, T. J.; Tan, W. ChemBioChem 2005, 6, 900-907. (h) Fang, X.; Sen, A.; Vicens, M.; Tan, W. ChemBioChem 2003, 4, 829834

(3) (a) Ross, R.; Raines, E. W.; Bowen-Pope, D. F. Cell 1986, 46, 155-169. (b) Deuel, T. F. Annu. Rev. Cell Biol. 1987, 3, 443-492. (c) Raff, M. C.; Lillien, L. E.; Richardson, W. D.; Burne, J. F.; Noble, M. D. Nature 1988, 333, 562-565. (d) Bejcek, B. E.; Li, D. Y.; Deuel, T. F. Science 1989, 245, 14961499. (e) Kim, H.-R. C.; Upadhyay, S.; Korsmeyer, S.; Deuel, T. F. J. Biol. Chem. 1994, 269, 30604-30608. (f) Deuel, T. F.; Senior, R. M.; Huang, J. S.; Griffin, G. L. J. Clin. Invest. 1982, 69, 1046-1049. (g) Huang, J. S.; Huang, S. S.; Deuel, T. F. Cell 1984, 39, 79-87.

(4) (a) Yu, J.; Ustach, C.; Kim, H.-R. C. J. Biochem. Mol. Biol. 2003, 36, 4959. (b) Alvarez, R. H.; Kantarjian, H. M.; Cortes, J. E. Mayo Clin. Proc. 2006, 81, 1241-1257. (c) Greco, A.; Roccato, E.; Miranda, C.; Cleris, L.; Formelli, F.; Pierotti, M. A. Int. J. Cancer 2001, 92, 354-360. (d) Kadono, T.; Kikuchi, K.; Nakagawa, H.; Tamaki, K. Dermatology 2000, 201, 10-14. (e) Sulzbacher, I.; Träxler, M.; Mosberger, I.; Lang, S.; Chott, A. Mod. Pathol. 2000 , 13, 632-637.

(5) (a) Joyce, G. F. Gene 1989, 82, 83-87. (b) Ellington, A. D.; Szostak, J. W. Nature 1990, 346, 818-822. (c) Tuerk, C.; Gold, L. Science 1990, 249, $505-510$.

(6) (a) Nutiu, R.; Li, Y. Chem.-Eur. J. 2004, 10, 1868-1876. (b) Nutiu, R.; Li, Y. J. Am. Chem. Soc. 2003, 125, 4771-4778. (c) Gokulrangan, G.; Unruh, J. R.; Holub, D. F.; Ingram, B.; Johnson, C. K.; Wilson, G. S. Anal. Chem. 2005, 77, 1963-1970. (d) Katilius, E.; Katiliene, Z.; Woodbury, N. W. Anal. Chem. 2006, 78, 6484-6489. (e) Yang, C. J.; Jockusch, S.; Vicens, M.; Turro, N. J.; Tan, W. Proc. Natl. Acad. Sci. U.S.A. 2005, 102, 17278-17283. (f) Jhaveri, S. D.; Kirby, R.; Conrad, R.; Maglott, E. J.; Bowser, M.; Kennedy, R. T.; Glick, G.; Ellington, A. D. J. Am. Chem. Soc. 2000, 122, 2469-2473. (g) Unruh, J. R.; Gokulrangan, G.; Lushington, G. H.; Johnson, C. K.; Wilson, G. S. Biophys. J. 2005, 88, 3455-3465. (h) Cao, Z.; Tan, W. Chem.-Eur. J. 2005, 11, 4502-4508

(7) (a) Stojanovic, M. N.; Kolpashchikov, D. M. J. Am. Chem. Soc. 2004, 126, 9266-9270. (b) Jiang, Y.; Fang, X.; Bai, C. Anal. Chem. 2004, 76, 52305235. (c) Stojanovic, M. N.; Landry, D. W. J. Am. Chem. Soc. 2002, 124, 9678-9679. (d) Ho, H.-A.; Leclerc, M. J. Am. Chem. Soc. 2004, 126, 1384- 
processes for labeling the probes or target analytes and the use of expensive fluorophores or coupling reagents (or both) are required. ${ }^{6}$ Thus, label-free and highly sensitive assays are highly demanded for trace analysis of proteins.?

Recently, bioconjugated gold nanoparticles (Au NPs) and quantum dots have been demonstrated as quenchers and fluorescent donors, respectively, for photoluminescence quenching. ${ }^{8}$ Quantum dots, such as CdSe@ZnS and CdTe@ZnS, offer several advantages over organic fluorophores for use as donors, including narrow band widths (usually $20-30 \mathrm{~nm}$ at the half-maximum) and size-dependent fluorescence emissions when excited at a particular wavelength. ${ }^{9}$ Photoluminescence quenching assays employing pairs of quantum dots with organic fluorophores, chromophores, other types of quantum dots and Au NPs have been demonstrated..$^{8-\mathrm{h}, 10}$ Concerns have been raised, however, regarding the toxicity of quantum dots; several studies have suggested that the cytotoxicity of quantum dots might be mediated by their release of $\mathrm{Cd}^{2+} .11$ Thus, there is a demand for the development of nontoxic photoluminescent NPs to replace potentially toxic quantum dots in bioassays.

In this study, we developed new competitive homogeneous photoluminescence quenching assays for analyzing proteins using bioconjugated photoluminescent $\mathrm{Au}$ nanodots $\left(\mathrm{L}_{\mathrm{AuND}}\right)$ as donors and bioconjugated spherical Au NPs as acceptors. We prepared

1387. (e) Liu, J.; Lu, Y. Angew. Chem. Int. Ed. 2006, 45, 90-94. (f) Pavlov, V.; Shlyahovsky, B.; Willner, I. J. Am. Chem. Soc. 2005, 127, 6522-6523. (g) Zhou, C.; Jiang, Y.; Hou, S.; Ma, B.; Fang, X.; Li, M. Anal. Bioanal. Chem. 2006, 384, 1175-1180.

(8) (a) Maxwell, D. J.; Taylor, J. R.; Nie, S. J. Am. Chem. Soc. 2002, 124, 96069612. (b) Dubertret, B.; Calame, M.; Libchaber, A. J. Nat. Biotechnol. 2001, 19, 365-370. (c) Li, H.; Rothberg, L. J. Anal. Chem. 2004, 76, 5414-5417. (d) Ao, L.; Gao, F.; Pan, B.; He, R.; Cui, D. Anal. Chem. 2006, 78, 11041106. (e) Medintz, I. L.; Clapp, A. R.; Mattoussi, H.; Goldman, E. R.; Fisher, B.; Mauro, J. M. Nat. Mater. 2003, 2, 630-638. (f) Chang, E.; Miller, J. S.; Sun, J.; Yu, W. W.; Colvin, V. L.; Drezek, R.; West, J. L. Biochem. Biophys. Res. Commun. 2005, 334, 1317-1321. (g) Xu, C.; Xing, B.; Rao, J. Biochem. Biophys. Res. Commun. 2006, 344, 931-935. (h) Shi, L.; Paoli, V. D.; Rosenzweig, N.; Rosenzweig, Z. J. Am. Chem. Soc. 2006, 128, 10378-10379.

(9) (a) Bruchez, M., Jr.; Moronne, M.; Gin, P.; Weiss, S.; Alivisatos, A. P. Science 1998, 281, 2013-2016. (b) Chan, W. C. W.; Nie, S. Science 1998, 281, 2016-2018. (c) Tran, P. T.; Goldman, E. R.; Anderson, G. P.; Mauro, J. M.; Mattoussi, H. Phys. Stat. Solidi B 2002, 229, 427-432. (d) Lin, Y.-W.; Hsieh, M.-M.; Liu, C.-P.; Chang, H.-T. Langmuir 2005, 21, 728-734. (e) Jaiswal, J. K.; Mattoussi, H.; Mauro, J. M.; Simon, S. M. Nat. Biotechnol. 2003, 21, 47-51. (f) Medintz, I. L.; Uyeda, H. T.; Goldman, E. R.; Mattoussi, H. Nat. Mater. 2005, 4, 435-446. (g) Alivisatos, A. P.; Gu, W.; Larabell, C. Annu. Rev. Biomed. Eng. 2005, 7, 55-76. (h) Costa-Fernández, J. M.; Pereiro, R.; Sanz-Medel, A. Trends Anal. Chem. 2006, 25, 207-218. (i) Clapp, A. R.; Medintz, I. L.; Fisher, B. R.; Anderson, G. P.; Mattoussi, H. J. Am. Chem. Soc. 2005, 127, 1242-1250.

(10) (a) Clapp, A. R.; Medintz, I. L.; Uyeda, H. T.; Fisher, B. R.; Goldman, E. R.; Bawendi, M. G.; Mattoussi, H. J. Am. Chem. Soc. 2005, 127, 18212-18221. (b) Levy, M.; Cater, S. F.; Ellington, A. D. ChemBioChem 2005, 6, 21632166. (c) Patolsky, F.; Gill, R.; Weizmann, Y.; Mokari, T.; Banin, U.; Willner, I. J. Am. Chem. Soc. 2003, 125, 13918-13919. (d) Gueroui, Z.; Libchaber, A. Phys. Rev. Lett. 2004, 93, 166108. (e) Dyadyusha, L.; Yin, H.; Jaiswal, S.; Brown, T.; Baumberg, J. J.; Booy, F. P.; Melvin, T. Chem. Commun. 2005 3201-3203. (f) Gill, R.; Willner, I.; Shweky, I.; Banin, U. J. Phys. Chem. B 2005, 109, 23715-23719. (g) Clapp, A. R.; Medintz, I. L.; Fisher, B. R.; Anderson, G. P.; Mattoussi, H. J. Am. Chem. Soc. 2005, 127, 1242-1250. (h) Wargnier, R.; Baranov, A. V.; Maslov, V. G.; Stsiapura, V.; Artemyev, M.; Pluot, M.; Sukhanova, A.; Nabiev, I. Nano Lett. 2004, 4, 451-457.

(11) (a) Hardman, R. Environ. Health Perspect. 2006, 114, 165-172. (b) Cho, S. J.; Maysinger, D.; Jain, M.; Röder, B.; Hackbarth, S.; Winnik, F. M. Langmuir 2007, 23, 1974-1980. (c) Zhang, Y.; Chen, W.; Zhang, J.; Liu, J.; Chen, G.; Pope, C. J. Nanosci. Nanotechnol. 2007, 7, 497-503. (d) Chang, E.; Thekkek, N.; Yu, W. W.; Colvin, V. L.; Drezek, R. Small 2006, 2, $1412-$ 1417. (e) Derfus, A. M.; Chan, W. C. W.; Bhatia, S. N. Nano Lett. 2004, 4, 11-18. a breast cancer marker protein, platelet-derived growth factor AA (PDGF AA)-bound $\mathrm{L}_{\mathrm{AuND}}$ (PDGF AA- $\mathrm{L}_{\mathrm{AuND}}$ ), from 11-mercaptoundecanoic acid (11-MUA)-protected $\mathrm{L}_{\mathrm{AuND}}(2.0 \pm 0.1 \mathrm{~nm}) .{ }^{12}$ Thiol-derivatized aptamer (Apt) molecules and 13-nm spherical $\mathrm{Au}$ NPs were used to prepare Apt- $\mathrm{Q}_{\mathrm{AuNP}}$ acceptors. The aptamer sequence was obtained through systematic evolution of ligands using an exponential enrichment (SELEX) process. ${ }^{5}$ It was reported to have a 700-fold higher affinity for PDGFs when compared with those of random DNA sequences; ${ }^{13}$ we confirmed this behavior in previous studies. ${ }^{14}$ Employing our two types of bioconjugated, Au-based nanomaterials, we have developed homogeneous assays for the selective and highly sensitive detection of PDGFs and one of their receptors (PDGF $\alpha$-receptor).

\section{EXPERIMENTAL SECTION}

Materials. The 5'-thiol-modified PDGF binding aptamer (5'CAG GCT ACG GCA CGT AGA GCA TCA CCA TGA TCC TG$3^{\prime}$ ) and $5^{\prime}$-thiol-modified $\alpha$-thrombin binding aptamer (5'-ACC CGT GGT AGG GTA GGA TGG GGT GGT-3') were purchased from Integrated DNA Technology, Inc. (Coralville, IA). Recombinant PDGF $\mathrm{AA}, \mathrm{BB}$, and $\mathrm{AB}$ and PDGF $\alpha$-receptor were purchased from R\&D Systems, Inc. (Minneapolis, MN). The PDGFs were dissolved in $4 \mathrm{mM} \mathrm{HCl}$, and PDGF $\alpha$-receptor was prepared in 5 $\mathrm{mM}$ phosphate solution ( $\mathrm{pH} 7.4 ; 135 \mathrm{mM} \mathrm{NaCl}$ ). The proteins insulin, $\beta$-casein, cytochrome $c$, carbonic anhydrase, trypsin inhibitor, BSA, trypsinogen, and lysozyme were obtained from Sigma (St. Louis, MO). Hydrogen tetrachloroaurate(III) trihydrate and all other reagents used in this study were purchased from Aldrich (Milwaukee, WI).

Synthesis of 13-nm Spherical Au NPs. The 13-nm spherical $\mathrm{Au}$ NPs were prepared through citrate-mediated reduction of $\mathrm{HAuCl}_{4} \cdot{ }^{15} \mathrm{~A} 250-\mathrm{mL}$ aqueous solution consisting of $1 \mathrm{mM} \mathrm{HAuCl}{ }_{4}$ was brought to a vigorous boil and stirred in a round-bottom flask fitted with a reflux condenser; $38.8 \mathrm{mM}$ trisodium citrate $(25 \mathrm{~mL})$ was then added rapidly to the solution. The solution was heated for another $15 \mathrm{~min}$, during which time its color changed from pale yellow to deep red. The solution was cooled to room temperature with continuous stirring. The sizes of the Au NPs were verified through TEM analysis (H7100, Hitachi HighTechnologies Corporation, Tokyo, Japan); they appeared to be nearly monodisperse, with an average size of $13.3 \pm 1.2 \mathrm{~nm}$. A double-beam UV-vis spectrophotometer (Cintra 10e, GBC, Victoria, Australia) was used to measure the absorption of the $\mathrm{Au}$ NP solution. The particle concentration of the Au NPs ( 15 nM) was determined according to Beer's law using an extinction coefficient of $\sim 10^{8} \mathrm{M}^{-1} \mathrm{~cm}^{-1}$ at $520 \mathrm{~nm}$ for the $13-\mathrm{nm} \mathrm{Au} \mathrm{NPs} .{ }^{15 \mathrm{c}}$

Preparation of Apt- $\mathbf{Q}_{\text {AuNP. }}$ The thiol-modified 35-mer DNA oligonucleotides were attached to the 13-nm Au NPs according

(12) Huang, C.-C.; Yang, Z.; Lee, K.-H.; Chang, H.-T. Angew. Chem., Int. Ed. 2007, $46,6824-6828$.

(13) Green, L. S.; Jellinek, D.; Jenison, R.; Östman, A.; Heldin, C.-H.; Janjic, N. Biochemistry 1996, 35, 14413-14424.

(14) (a) Huang, C.-C.; Huang, Y.-F.; Cao, Z.; Tan, W.; Chang, H.-T. Anal. Chem. 2005, 77, 5735-5741. (b) Huang, C.-C.; Chiu, S.-H.; Huang, Y.-F.; Chang, H.-T. Anal. Chem. 2007, 79, 4798-4804.

(15) (a) Frens, G. Nat. Phys. Sci. 1973, 241, 20-22. (b) Grabar, K. C.; Freeman, R. G.; Hommer, M. B.; Natan, M. J. Anal. Chem. 1995, 67, 735-743. (c) Mucic, R. C.; Storhoff, J. J.; Mirkin, C. A.; Letsinger, R. L. J. Am. Chem. Soc. 1998, 120, 12674-12675. 
to modified literature procedures. ${ }^{16}$ The $5^{\prime}$-thiol-modified oligonucleotides were received in disulfide form $\left[\mathrm{HOCH}_{3}\left(\mathrm{CH}_{2}\right)_{5} \mathrm{~S}-\mathrm{S}-\right.$ 5 -oligo], protected by mercaptohexanol groups. These oligonucleotides were reacted directly with the Au NPs through attachment of both the $\mathrm{HOCH}_{3}\left(\mathrm{CH}_{2}\right)_{5} \mathrm{~S}-$ and oligo-S- units onto the $\mathrm{Au} \mathrm{NP}$ surface. Two aliquots of aqueous Au NP solutions $(800 \mu \mathrm{L})$ in 1.5-mL tubes were mixed separately with the thio-oligonucleotides $(5.0 \mu \mathrm{M}, 200 \mu \mathrm{L})$ to obtain a final concentration of $12 \mathrm{nM}$ Au NPs and $1.0 \mu \mathrm{M}$ oligonucleotides. After reaction for $24 \mathrm{~h}$ at room temperature, the mixtures were centrifuged for $25 \mathrm{~min}$ at $19000 \mathrm{~g}$ to remove the excess thiol-DNA. Following removal of the supernatants, the oily precipitates were washed with $5 \mathrm{mM}$ trisodium citrate. After two wash/centrifuge cycles, the Apt $-\mathrm{Q}_{\text {AuNP }}$ samples were resuspended separately in $5 \mathrm{mM}$ trisodium citrate and stored in a refrigerator $\left(4^{\circ} \mathrm{C}\right)$. Finally, the Apt- $\mathrm{Q}_{\text {AuNP }}$ samples were equilibrated separately with $0.1 \%$ poly (ethylene glycol) (PEG; Mw: 8000) for $2 \mathrm{~h}$ at room-temperature prior to use in the detection of PDGFs. The PEG-modified Apt-Q $\mathrm{Q}_{\text {AuNP }}$ samples prevented nonspecific binding with interference proteins. ${ }^{14}$ Moreover, the Apt- $\mathrm{Q}_{\text {AuNP }}$ samples were stable in solutions containing $\mathrm{NaCl}$ at concentrations up to $250 \mathrm{mM}$. To determine the number of oligos on each Apt-Q $\mathrm{Q}_{\text {AuNP, }}$ a solution of 2-mercaptoethanol (1.0 $\mathrm{M}, 10 \mu \mathrm{L}$ ) was used to displace the oligonucleotide molecules from the surfaces of the Apt- $\mathrm{Q}_{\text {AuNP }}(12 \mathrm{nM}, 990 \mu \mathrm{L})$. The concentration of displaced oligonucleotides in the supernatant was used to calculate the quantity on each Apt- $Q_{\text {AuNP }}$ particle. Our calculations indicated that $\sim 40$ oligonucleotide molecules were attached to each Apt $-Q_{\text {AuNP. }}$.

Synthesis of PDGF AA- $\mathbf{L}_{\text {AuND }}$. The $\mathrm{L}_{\text {AuND }}$ samples were first synthesized through reduction of $\mathrm{HAuCl}_{4} \cdot 3 \mathrm{H}_{2} \mathrm{O}$ with tetrakis(hydroxymethyl)phosphonium chloride (THPC). ${ }^{17} \mathrm{NaOH}(1.0 \mathrm{~N}$, $0.5 \mathrm{~mL})$ was added to water $(45 \mathrm{~mL})$, followed by the addition of a THPC solution $(1 \mathrm{~mL})$, which had been prepared by adding $80 \%$ THPC solution $(12 \mu \mathrm{L})$ to water $(1 \mathrm{~mL})$. The mixture was stirred for $5 \mathrm{~min}$, followed by rapid addition of $1.0 \mathrm{wt} \% \mathrm{HAuCl}_{4}$. $3 \mathrm{H}_{2} \mathrm{O}(1.5 \mathrm{~mL})$. The color of the solution turned brown over the course of $1 \mathrm{~min}$. Prior to use, the solution was stored at $4{ }^{\circ} \mathrm{C}$. The sizes of the as-prepared spherical Au NPs were determined using high-resolution transmission electron microscopy (HRTEM; Tecnai 20 G2 S-Twin TEM, Philips/FEI, Hillsboro, OR); the average size was $2.9( \pm 0.5) \mathrm{nm}$. The particle concentration of the as-prepared Au NP solution $(\sim 0.94 \mu \mathrm{M})$ was determined according to a procedure described previously. ${ }^{12}$

The Au NPs were self-assembled with 11-MUA molecules by introducing 11-MUA stock solutions $(100 \mathrm{mM})$ into the asprepared Au NP solution at a concentration of $0.47 \mu \mathrm{M}$. The asprepared Au NP solution $(5.0 \mathrm{~mL})$, DI water $(3.0 \mathrm{~mL})$, sodium tetraborate $(50 \mathrm{mM}, \mathrm{pH} 9.2,1.0 \mathrm{~mL})$, and 11-MUA $(1.0 \mathrm{~mL}, 100$ $\mathrm{mM}$ ) were added, in that order, to a $10-\mathrm{mL}$ volumetric flask. The mixture was left to react for $72 \mathrm{~h}$ in the dark at room temperature. The resulting $\mathrm{L}_{\mathrm{AuND}}$ with strong photoluminescence were designated as 11-MUA- $\mathrm{L}_{\mathrm{AuND}}$. The excess 11-MUA in the solution was removed through centrifugal filtration $(13500 \mathrm{~g})$ for $40 \mathrm{~min}$ through a filter having a cutoff of $10 \mathrm{kDa}$. The 11-MUA- $\mathrm{L}_{\mathrm{AuND}}$ solution

(16) Storhoff, J. J.; Elghanian, R.; Mucic, R. C.; Mirkin, C. A.; Letsinger, R. L. J. Am. Chem. Soc. 1998, 120, 1959-1964.

(17) (a) Duff, D. G.; Baiker, A. Langmuir 1993, 9, 2301-2309. (b) Stoeva, S. I.; Huo, F.; Lee, J.-S.; Mirkin, C. A. J. Am. Chem. Soc. 2005, 127, 1536215363. was then resuspended in $5 \mathrm{mM}$ sodium phosphate solution ( $\mathrm{pH}$ 7.4). By comparing the absorbance of the original 11-MUA- $\mathrm{L}_{\mathrm{AuND}}$ solution at $375 \mathrm{~nm}$ to that of the resuspended solution, $95 \%$ of the 11-MUA- $\mathrm{L}_{\text {AunD }}$ was deemed to have been collected (data not shown). The corresponding particle concentration in the resuspended solution was estimated to be $1.5 \mu \mathrm{M}$, provided that the 11-MUA- $\mathrm{L}_{\mathrm{AuND}}$ had a uniform diameter of $2.0( \pm 0.1) \mathrm{nm}$, which was estimated from a count of $10011-M U A-\mathrm{L}_{\text {AuND }}$ particles in a TEM image. The purified 11-MUA- $\mathrm{L}_{\mathrm{AuND}}$ sample was stable for at least 3 months when stored at $4{ }^{\circ} \mathrm{C}$ in the dark. The absorption and photoluminescence spectra of the as-prepared 11-MUA- $\mathrm{L}_{\text {AuND }}$ solutions were measured using UV-vis absorption and fluorescence spectrophotometers (Cary Eclipse; Varian, CA), respectively.

For preparation of the PDGF $\mathrm{AA}-\mathrm{L}_{\mathrm{AuND}}$ stock solution, a mixture of purified 11-MUA- $\mathrm{L}_{\text {Aund }}(40 \mathrm{nM})$ and PDGF AA (80 $\mathrm{nM})$ in $5 \mathrm{mM}$ sodium phosphate ( $\mathrm{pH}$ 7.4) was left for $2 \mathrm{~h}$ at room temperature. PDGF AA molecules readily conjugated to $\mathrm{L}_{\mathrm{AuND}}$ through electrostatic and hydrophobic interactions. A similar method was applied to the preparation of thrombin- $\mathrm{L}_{\mathrm{AuND}}$; the concentration of thrombin was $200 \mathrm{nM}$. The as-prepared PDGF $\mathrm{AA}-\mathrm{L}_{\mathrm{AuND}}$ and thrombin $-\mathrm{L}_{\mathrm{AuND}}$ solutions were stable for at least 3 days when stored at $4{ }^{\circ} \mathrm{C}$ in the dark.

Cell Culture. The breast cancer cell line HTB-26 was used in this study. Cells were cultured in Leibovitz's L-15 medium (Gibco BRL, New York) plus 10\% fetal bovine serum (FBS; Gibco). Cells were grown at $37{ }^{\circ} \mathrm{C}$ in a humidified atmosphere containing $5 \%$ $\mathrm{CO}_{2}$ (in air). The medium was changed every 3 days. At $\sim 80 \%$ confluency, the cells were trypsinized with trypsin-EDTA solution (0.25\% trypsin, $1 \mathrm{mM}$ EDTA) for $5-10 \mathrm{~min}$ at $37^{\circ} \mathrm{C}$ to detach the cells for reseeding and growing in new culture dishes at a density of $\sim 2.2 \times 10^{5}$ per culture dish. After $24 \mathrm{~h}$, the medium was removed, fresh serum-free conditioned media (Minimum Essential Medium Alpha Medium) was added, and the cells were incubated at $37^{\circ} \mathrm{C}$ for $40 \mathrm{~h}$. The serum-free cell medium was then collected and filtered through a $0.2-\mu \mathrm{m}$ filter.

Urine Samples. A urine sample from a healthy volunteer was filtered through a $0.2-\mu \mathrm{m}$ membrane and then diluted 5 -fold with buffer (5 mM sodium phosphate, $200 \mathrm{mM} \mathrm{NaCl}$; $\mathrm{pH}$ 7.4). The solution was then analyzed using the described probe following the processes similar to that used for the cell media.

Competitive Assays of PDGFs, Thrombin, and PDGF $\alpha$-Receptor. Aliquots $(0.2 \mathrm{~mL})$ of $0.2 \mathrm{M}$ phosphate solutions containing $200 \mathrm{mM} \mathrm{NaCl}$ and PDGF AA- $\mathrm{L}_{\mathrm{AuND}}(4.0 \mathrm{nM})$ and $\mathrm{Apt}-$ $\mathrm{Q}_{\mathrm{AuNP}}(0.4 \mathrm{nM})$ in the presence of PDGFs $(0-2.0 \mathrm{nM})$ were equilibrated at room temperature for $1 \mathrm{~h}$. All solutions were then transferred into 0.4-mL quartz cuvettes; their photoluminescence spectra were measured when operating the fluorescence spectrophotometer at an excitation wavelength of $375 \mathrm{~nm}$. The real sample solutions were analyzed using the described probe following the processes similar to that used for cell media.

\section{RESULTS AND DISCUSSION}

Optical Properties of PDGF AA- $\mathbf{L}_{\text {AuND }}$. In a previous study, we prepared water-soluble alkanethiol- $\mathrm{L}_{\mathrm{AuND}}$ having tunable photoluminescence wavelengths $(501-618 \mathrm{~nm})$, when excited at $375 \mathrm{~nm}$, through modification of the chain length of the alkanethiol. ${ }^{12}$ Because 11-MUA- $\mathrm{L}_{\text {Aund }}$ photoluminescence at the wavelengths $\left(\lambda_{\max }^{\mathrm{em}}\right)$ was centered at $520 \mathrm{~nm}$, which overlaps to a 
(A)

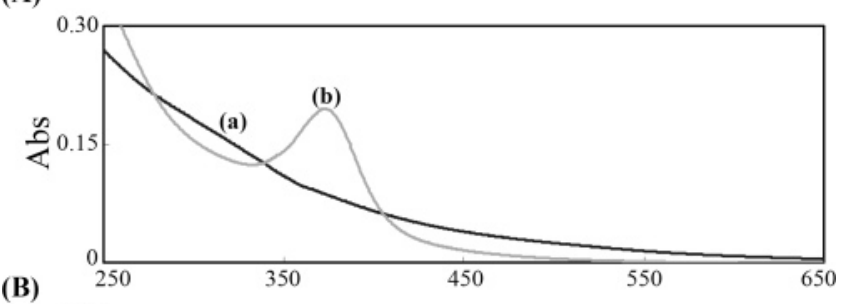

(B)

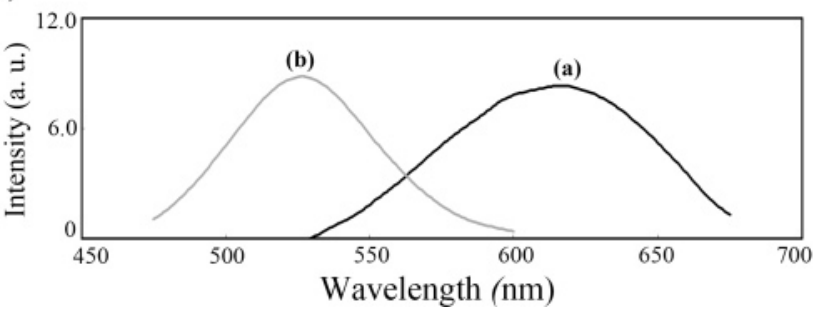

Figure 1. (A) UV-vis absorbance and (B) photoluminescence spectra of (a) Au NPs and (b) 11-MUA-LAund. The photoluminescence intensities are plotted in arbitrary units (a. u.); excitation wavelength: $375 \mathrm{~nm}$. The concentrations of the $\mathrm{Au} \mathrm{NPs}$ and 11-MUA-LAund in (B) were $0.94 \mu \mathrm{M}$ and $0.15 \mathrm{nM}$, respectively.

great extent with the surface plasmon resonance (SPR) band of the 13-nm $\mathrm{Q}_{\mathrm{AuNP}}$, we chose them for use as donors. From HRTEM measurements, we determined the sizes of the as-prepared $\mathrm{Au}$ NPs and 11-MUA- $\mathrm{L}_{\text {AuND }}$ from a count of 100 particles to be 2.9 $( \pm 0.5)$ and $2.0 \pm 0.1 \mathrm{~nm}$, respectively (data not shown). The decreased size of the Au NPs in the presence of 11-MUA is due to the very strongly covalent, distinctly directional $\mathrm{Au}-\mathrm{S}$ bond and preference of dissociation into very smaller $\mathrm{Au}$ and gold thiolate clusters (on the basis of fragmentation energies), as opposed to breaking the $\mathrm{Au}-\mathrm{S}$ bond and detaching the Au cluster from the thiolate radical. ${ }^{18}$ Although the 11-MUA- $\mathrm{L}_{\mathrm{AuND}}$ exhibited an absorption band centered at a wavelength $\left(\lambda_{\max }^{\text {abs }}\right)$ of $375 \mathrm{~nm}$, no apparent absorption band appeared for the Au NPs (Figure $1 \mathrm{~A})$. The absorption bands for $11-\mathrm{MUA}-\mathrm{L}_{\mathrm{AuNDs}}$ originate from metal-center ( $\mathrm{Au} 5 \mathrm{~d}^{10}$ to $6 \mathrm{sp}$ interband transitions), ligand-metal charge-transfer transitions, or both. ${ }^{19,20}$ The photoluminescent bands of the Au NPs and 11-MUA- $\mathrm{L}_{\text {AuND }}$ were centered at wavelengths of 618 and $520 \mathrm{~nm}$, respectively (Figure 1B). Upon decreasing the size of the protected Au nanoclusters, the emission wavelength underwent a blue shift. ${ }^{12,21} \mathrm{We}$ note that the photoluminescence intensity of the $11-\mathrm{MUA}-\mathrm{L}_{\mathrm{AuND}}$ was $\sim 60000$-fold

(18) (a) Krüger, D.; Fuchs, H.; Rousseau, R.; Marx, D.; Parrinello, M. J. Chem. Phys. 2001, 115, 4776-4786. (b) Konôpka, M.; Rousseau, R.; Štich, I.; Marx, D. J. Am. Chem. Soc. 2004, 126, 12103-12111.

(19) (a) Link, S.; El-Sayed, M. A.; Schaaff, T. G.; Whetten, R. L. Chem. Phys. Lett. 2002, 356, 240-246. (b) Huang, T.; Murray, R. W. J. Phys. Chem. B 2001, 105, 12498-12502. (c) Yang, Y.; Chen, S. Nano Lett. 2003, 3, 7579. (d) Negishi, Y.; Tsukuda, T. Chem. Phys. Lett. 2004, 383, 161-165. (e) Wang, G.; Huang, T.; Murray, R. W.; Menard, L.; Nuzzo, R. G. J. Am. Chem. Soc. 2005, 127, 812-813. (f) Negishi, Y.; Nobusada, K.; Tsukuda, T. J. Am. Chem. Soc. 2005, 127, 5261-5270. (g) Wang, G.; Guo, R.; Kalyuzhny, G.; Choi, J.P.; Murray, R. W. J. Phys. Chem. B 2006, 110, 20282-20289.

(20) (a) Zheng, J.; Zhang, C.; Dickson, R. M. Phys. Rev. Lett. 2004, 93, 077402. (b) Zheng, J.; Petty, J. T.; Dickson, R. M. J. Am. Chem. Soc. 2003, 125, 7780-7781. (c) Tran, M. L.; Zvyagin, A. V.; Plakhotnik, T. Chem. Commun. 2006, 2400-2401. (d) Shi, X.; Ganser, T. R.; Sun, K.; Balogh, L. P.; Baker, J. R., Jr. Nanotechnology 2006, 17, 1072-1078. (e) Duan, H.; Nie, S. J. Am. Chem. Soc. 2007, 129, 2412-2413. (f) Triulzi, R. C.; Micic, M.; Giordani, S.; Serry, M.; Chiou, W.-A.; Leblanc, R. M. Chem. Commun. 2006, 50685070.

(21) Schaaff, T. G.; Whetten, R. L. J. Phys. Chem. B 2000, 104, 2630-2641.

\section{Scheme 1. Schematic Representations of PDGF and PDGF Receptor Nanosensors That Operate Based on the Modulation of the Photoluminescence Quenching between PDGF AA $-L_{\text {AUND }}$ and Apt $-Q_{\text {AuNP }}{ }^{a}$}

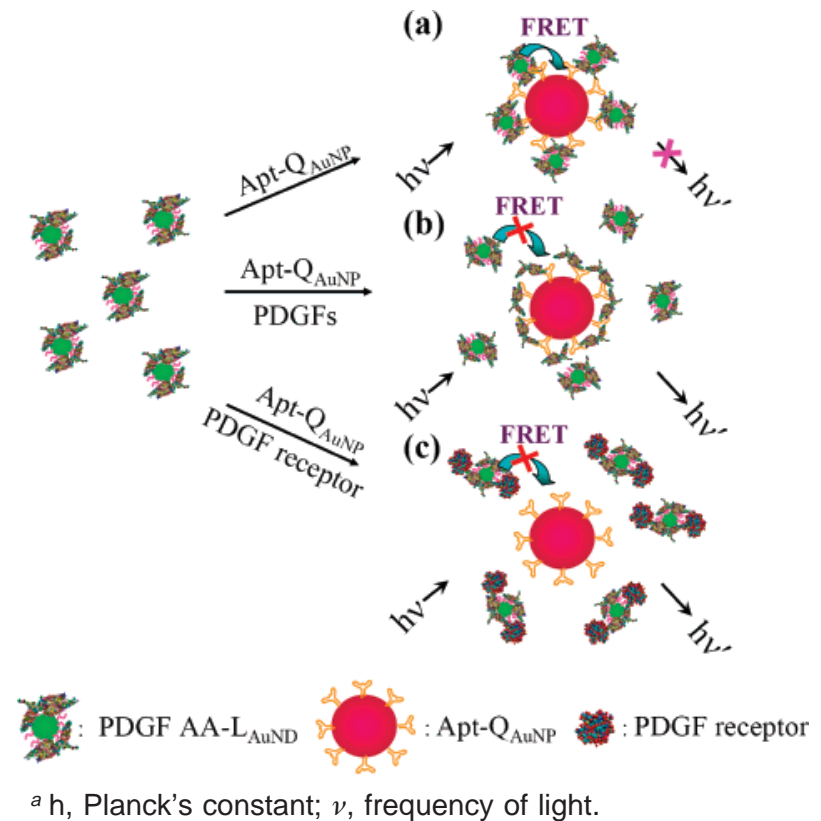

higher than that of the Au NPs. The quantum yield of the asprepared 11-MUA- $\mathrm{L}_{\mathrm{AuND}}$ was determined to be $3.1 \%$ through comparison with quinine (QY 53\%). This QY is comparable to those of the best currently available water-soluble alkanethiol ligand-protected Au NPs. ${ }^{19}$

The purification of 11-MUA- $\mathrm{L}_{\mathrm{AuND}}$ was accomplished by centrifugal filtration $(13500 \mathrm{~g})$ for $40 \mathrm{~min}$ through a filter having a cutoff of $10 \mathrm{kDa}$. Comparison with the original 11-MUA- $\mathrm{L}_{\mathrm{AuND}}$ solution showed that there is very weak photoluminescence in the removed solution, which can be detected at an excitation wavelength of $375 \mathrm{~nm}$. It means the photoluminescence signal is truly from 11-MUA- $\mathrm{L}_{\mathrm{AuND}}$. The 11-MUA- $\mathrm{L}_{\mathrm{AuND}}$ pellets were then resuspended in $5 \mathrm{mM}$ sodium phosphate solution ( $\mathrm{pH}$ 7.4). By comparing the absorbance of the original 11-MUA- $\mathrm{L}_{\mathrm{AuND}}$ solution at $375 \mathrm{~nm}$ to that of the resuspended solution, $95 \%$ of the 11 MUA- $\mathrm{L}_{\mathrm{AuND}}$ was deemed to have been collected (data not shown). Our prepared 11-MUA- $\mathrm{L}_{\mathrm{AuND}}$ solution was stable in aqueous solution at $4{ }^{\circ} \mathrm{C}$ for at least 3 months. From a practical point of view, it is important to test the stability of the as-prepared 11MUA- $\mathrm{L}_{\text {AuND }}$ solution under physiological conditions. We found that our prepared 11-MUA- $\mathrm{L}_{\mathrm{AuND}}$ solution was stable in sodium phosphate $(10 \mathrm{mM}$; $\mathrm{pH} 4.00-11.00)$ solutions containing $\mathrm{NaCl}$ at concentrations of up to $250 \mathrm{mM}$ (Figure S1, Supporting Information). The 11-MUA- $\mathrm{L}_{\mathrm{AuND}}$ sample was then used to prepare PDGF $\mathrm{AA}-\mathrm{L}_{\mathrm{AuND}}$, in which PDGF AA molecules were bioconjugated with 11-MUA- $\mathrm{L}_{\mathrm{AuND}}$ through electrostatic and hydrophobic interactions. 12,22

The photoluminescence intensity of PDGF $\mathrm{AA}-\mathrm{L}_{\mathrm{AuND}}$ increased initially upon increasing the concentration of PDGF AA before reaching a plateau (Figure S2, Supporting Information). PDGF AA protected the 11-MUA- $\mathrm{L}_{\mathrm{AuND}}$ from quenchers present

(22) Liu, C.-W.; Chang, H.-T. Open Anal. Chem. J. 2007, 1, 1-6. 


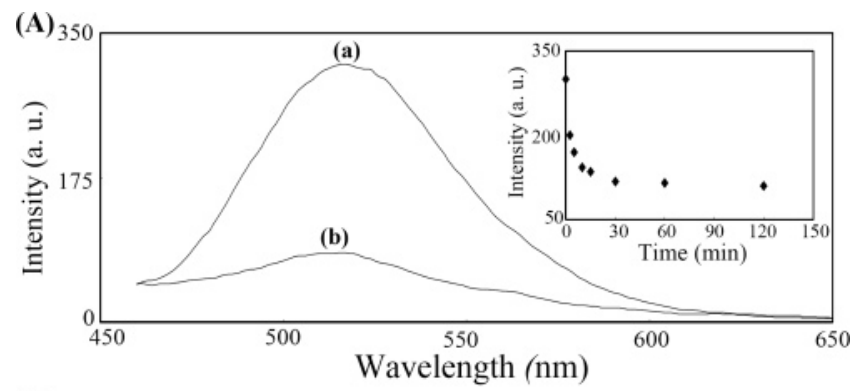

(B)

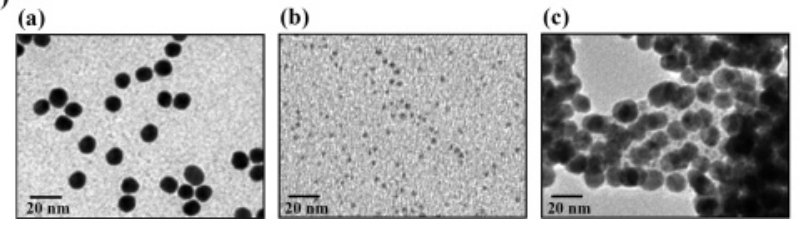

Figure 2. (A) Photoluminescence spectra of solutions containing PDGF AA- LAuND $_{\text {A }}(4.0 \mathrm{nM})$ in the (a) absence and (b) presence of Apt $-Q_{\text {AuNP }}(0.6 \mathrm{nM})$ in $5 \mathrm{mM}$ sodium phosphate $(\mathrm{pH} 7.4)$ containing $200 \mathrm{mM} \mathrm{NaCl}$. Inset: Time-course measurement of the photoluminescence intensity at $520 \mathrm{~nm}$ for PDGF $A A-L_{A u N D}$ after the addition of Apt-Q $Q_{\text {Aunp. (B) }}$ HRTEM images of (a) Apt- $Q_{\text {AunP, }}$ (b) PDGF AA$L_{\text {Aund, }}$ and (c) mixture of Apt- $-Q_{\text {AunP }}$ and PDGF $A A-L_{\text {Aund. Other }}$ conditions were the same as those described in Figure 1.

in solution, thereby increasing the photoluminescence of 11MUA- $\mathrm{L}_{\mathrm{AuND}}$. The saturated binding ratio [PDGF AA]/[11-MUA$\mathrm{L}_{\mathrm{AuND}}$ ] was close to 2, suggesting that two PDGF AA molecules were present on each 11-MUA- $\mathrm{L}_{\mathrm{AuND}}$. The as-prepared PDGF $\mathrm{AA}-\mathrm{L}_{\mathrm{AuND}}$ solution was even more stable than the 11-MUA- $\mathrm{L}_{\mathrm{AuND}}$ solution under physiological conditions (up to $1.0 \mathrm{M} \mathrm{NaCl}$ ).

Assay Strategy. Scheme 1 illustrates that, by employing aptamer-protein interactions, the concentrations of PDGFs and their receptors in sample solutions can be determined. The photoluminescence of PDGF AA- $\mathrm{L}_{\text {AuND }}$ at $520 \mathrm{~nm}$ decreased when photoluminescence quenching occurred between Apt- $Q_{\text {AuNP }}$ and PDGF AA- $\mathrm{L}_{\mathrm{AuND}}$ (route a). In the presence of PDGFs (route b), the interaction between Apt- $\mathrm{Q}_{\mathrm{AuNP}}$ and PDGF AA- $\mathrm{L}_{\mathrm{AuND}}$ decreased as a result of competitive reactions between the PDGFs and $A p t-Q_{\text {AuNP. }}$ As a consequence, the photoluminescence quenching efficiency between Apt $-\mathrm{Q}_{\mathrm{AuNP}}$ and PDGF AA- $\mathrm{L}_{\mathrm{AuND}}$ decreased, and photoluminescence at $520 \mathrm{~nm}$ occurred to a greater extent. Similarly, the interaction between Apt $-Q_{\mathrm{AuNP}}$ and PDGF AA $-\mathrm{L}_{\mathrm{AuND}}$ decreased as a result of competitive reactions between PDGF $\alpha$-receptor and PDGF AA- $\mathrm{L}_{\text {Aund }}$ (route c), resulting in decreased photoluminescence quenching efficiency between Apt $-\mathrm{Q}_{\mathrm{AuNP}}$ and PDGF AA- $\mathrm{L}_{\mathrm{AuND}}$ and increased photoluminescence at $520 \mathrm{~nm}$.

Photoluminescence Quenching of PDGF AA- $\mathrm{L}_{\text {AuND }}$ by Apt $-\mathbf{Q}_{\text {AuNP. }}$. To test our photoluminescence quenching assay, we added PDGF AA- $\mathrm{L}_{\mathrm{AuND}}$ into a solution of Apt $-\mathrm{Q}_{\mathrm{AuNP}}$. As a result of specific interactions between the aptamer and PDGF AA molecules, the PDGF AA- $\mathrm{L}_{\mathrm{AuND}}$ sample photoluminesced more weakly in the presence of Apt- $\mathrm{Q}_{\mathrm{AuNP}}$ (Figure 2A). The photoluminescence at $520 \mathrm{~nm}$ of the mixture reached a state of equilibrium within $\sim 30 \mathrm{~min}$ (the inset in Figure 2A). TEM images of Apt $-\mathrm{Q}_{\mathrm{AuNP}}, \mathrm{PDGF} \mathrm{AA}-\mathrm{L}_{\mathrm{AuND}}$, and their mixture support our reasoning (Figure 2B). At a constant concentration of Apt $-\mathrm{Q}_{\mathrm{AuNP}}$ $(0.6 \mathrm{nM})$, the mixtures at different molar ratios of [PDGF AA]/ [11-MUA- $\mathrm{L}_{\mathrm{AuND}}$ ] had various photoluminescence intensities at 520
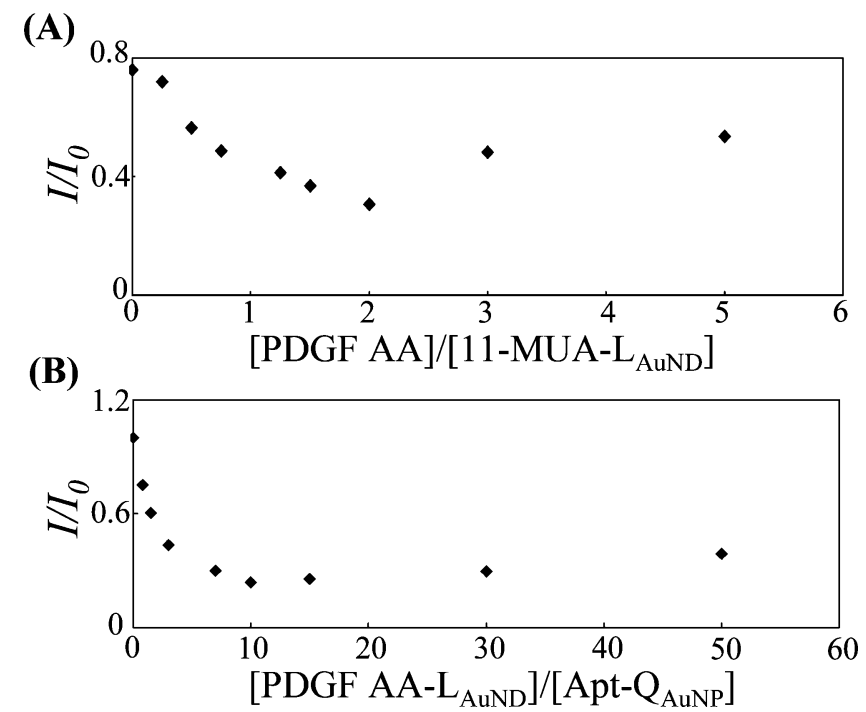

Figure 3. (A) Quenching efficiency $\left(I / I_{0}\right)$ of PDGF $A A-L_{A u N D}(4 \mathrm{nM})$ at $520 \mathrm{~nm}$ plotted with respect to the concentration ratio of [PDGF $A A] /\left[11-M U A-L_{A u N D}\right]$ at a fixed concentration of Apt $-Q_{\text {AunP }}(0.6 \mathrm{nM})$. (B) Quenching efficiency $\left(I / I_{0}\right)$ of PDGF AA- $\mathrm{L}_{\text {AuND }}(4 \mathrm{nM})$ at $520 \mathrm{~nm}$ plotted with respect to the concentration ratio of [PDGF $\left.A A-L_{A u N D}\right] /$ [Apt-Q $-Q_{\text {AuNP] }}$. Buffer: $5 \mathrm{mM}$ sodium phosphate $(\mathrm{pH} 7.4)$ containing $200 \mathrm{mM} \mathrm{NaCl}$. $l$ and $I_{0}$ are the photoluminescence intensities of the PDGF AA- $L_{\text {AunD }}$ in the absence and presence of Apt- $Q_{\text {AunN. }}$ Other conditions were the same as those described in Figure 1.

$\mathrm{nm}$, reaching a plateau at a molar ratio of 2 (Figure 3A). Figure S3 (Supporting Information) displays that the SPR absorption of the Apt $-\mathrm{Q}_{\mathrm{AuNP}}$ solutions are different in the absence and presence of various amounts of PDGF AA- $\mathrm{L}_{\mathrm{AuND}}$. The specific interactions between the PDGF and aptamer molecules induced interparticle cross-linking among PDGF AA- $\mathrm{L}_{\text {AuND }}$ and Apt $-\mathrm{Q}_{\text {AuNP. }}$. The degree of aggregation of PDGF $\mathrm{AA}-\mathrm{L}_{\mathrm{AuND}}$ and Apt $-\mathrm{Q}_{\mathrm{AuNP}}$ is highly dependent on the molar ratios of [PDGF AA]/[11-MUA- $\left.\mathrm{L}_{\mathrm{AuND}}\right]$ and coincide with the photoluminescence quenching of PDGF $\mathrm{AA}-\mathrm{L}_{\mathrm{AuND}}$ by Apt $-\mathrm{Q}_{\mathrm{AuNP}}$, as shown in Figure $3 \mathrm{~A} .{ }^{14 a}$ We thus suggest that photoluminescence quenching is through resonance energy transfer and aggregation of particles. ${ }^{10 \mathrm{~d}, \mathrm{e}, 12,15 \mathrm{c}}$ At higher PDGF concentrations, aggregation occurred to a lesser extent as a result of electrostatic repulsion among the PDGF AA- $\mathrm{L}_{\mathrm{AuND}} \cdot{ }^{14 \mathrm{a}}$ At a constant concentration of PDGF AA- $\mathrm{L}_{\mathrm{AuND}}$, we found that the optimum ratio of $\left[\mathrm{PDGF} A A-\mathrm{L}_{\mathrm{AuND}}\right] /\left[\mathrm{Apt}-\mathrm{Q}_{\mathrm{AuNP}}\right]$ was 10 (Figure $3 \mathrm{~B})$. We suggest that the saturated binding with PDGF $\mathrm{AA}-\mathrm{L}_{\mathrm{AuND}}$ of each Apt-$-\mathrm{Q}_{\mathrm{AuNP}}$ particle was $\sim 10$, with this value arising mainly from the binding of PDGF AA and aptamer (1:2) and the relative size of $\mathrm{L}_{\mathrm{AuND}}$ and $\mathrm{Q}_{\mathrm{AuNP}}(2: 13)$.

Competitive Assays of PDGFs. We used the optimum conditions (4 nM PDGF AA- $\mathrm{L}_{\text {AuND }}$ (two PDGF molecules on each $\mathrm{L}_{\mathrm{AuND}}$ ) and $0.4 \mathrm{nM} \mathrm{Apt}-\mathrm{Q}_{\mathrm{AuNP}}$ in sodium phosphate solution (5 $\mathrm{mM}, \mathrm{pH} 7.4,200 \mathrm{mM} \mathrm{NaCl})^{14 a}$ ) to determine the concentrations of PDGFs in solution. The photoluminescence of the mixtures increased upon increasing the concentration of PDGFs over the range $0.1-2.0 \mathrm{nM}$ (Figure 4A). The linear relationships for all three PDGFs were from 0.1 to $1.0 \mathrm{nM}$, with correlation coefficients $>0.94$. The limit of detection (LOD) for each of the three PDGFs was $80 \mathrm{pM}$, on the basis of a signal-to-noise ratio $(\mathrm{S} / \mathrm{N})$ of 3 ; these values are comparable with those obtained using other signaling aptamer reporters. ${ }^{6 \mathrm{~d}, \mathrm{e}, \mathrm{fb}, \mathrm{g}}$ The highly sensitive detection of PDGFs by PDGF AA- $\mathrm{L}_{\mathrm{AuND}} / \mathrm{Apt}-\mathrm{Q}_{\mathrm{AuNP}}$ is due to a low background signal 

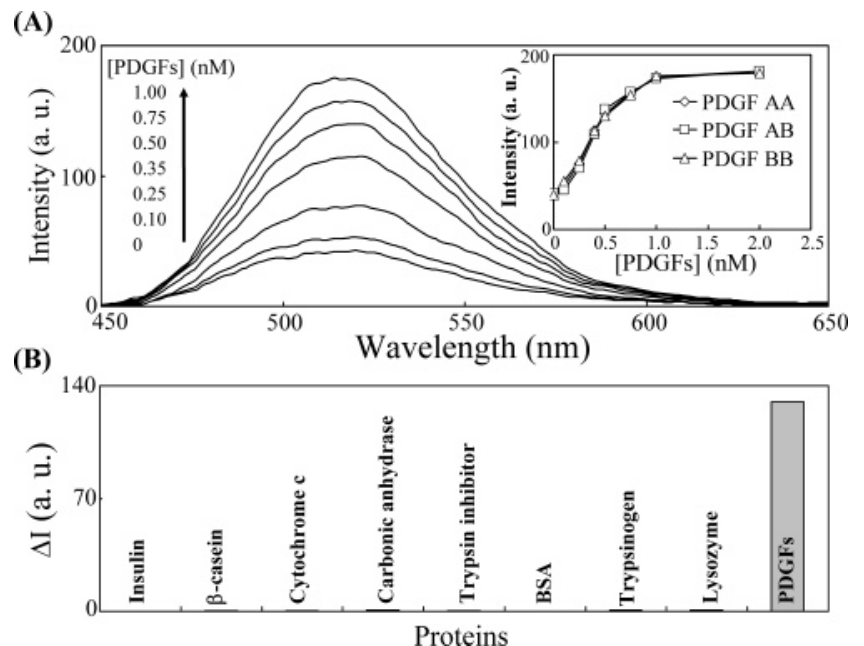

Figure 4. (A) Competitive binding assay for PDGFs using the PDGF $A A-L_{\text {Aund }} / A p t-Q_{\text {AunP }}$ probe. (B) Photoluminescence changes of the PDGF $A A-L_{A u N D}$ probe toward PDGFs and other proteins. Other conditions were the same as those described in Figure 3B.

and a signal enhancement of up to 3-fold upon addition of PDGFs at the saturated concentration. PDGFs exist as disulfide-linked dimers of two polypeptide chains ( $\mathrm{A}$ and $\mathrm{B}$ ) in three isoforms (PDGF AA, $\mathrm{BB}$, and $\mathrm{AB})$; $23 \mathrm{a}$ they are growth factor proteins in human platelets and have growth-promoting activity for fibroblasts, smooth muscle cells, and glial cells. ${ }^{4,23 b-d}$

Interestingly, the sensitivities of PDGF AA, PDGF AB, and PDGF BB were almost the same, a situation that does not correlate with the order of the stabilities of the Apt-PDGF complexes in free solution: PDGF BB > PDGF AB > PDGF AA..$^{13}$ We believe that this behavior is due to changes in the structures of the aptamer molecules or the PDGFs on the Au NP surface and a multivalent binding effect (ultrahigh densities of aptamer on the local surface of $\mathrm{Q}_{\mathrm{AuNP}}$ ) that increases the binding affinity of PDGFs to Apt-Q AunP. $^{14,24}$

Our PDGF AA- $\mathrm{L}_{\mathrm{AuND}} / \mathrm{Apt}-\mathrm{Q}_{\mathrm{AuNP}}$ system can detect total PDGF concentrations in real samples because the sensitivities for the three PDGFs are identical. To test the specificity of this assay toward PDGFs, we incubated aliquots of the mixtures of PDGF $\mathrm{AA}-\mathrm{L}_{\mathrm{AuND}}(4 \mathrm{nM})$ and $\mathrm{Apt}-\mathrm{Q}_{\mathrm{AuNP}}(0.4 \mathrm{nM})$ in the presence of PDGFs $(1.0 \mathrm{nM})$ and some possible interfering proteins (including insulin, $\beta$-casein, cytochrome $c$, carbonic anhydrase, trypsin inhibitor, BSA, trypsinogen, and lysozyme $(1.0 \mathrm{nM}))$ that might be present in biological samples, such as blood. The responses to photoluminescence changes of PDGF AA- $\mathrm{L}_{\mathrm{AuND}} / \mathrm{Apt}-\mathrm{Q}_{\mathrm{AuNP}}$ with and without the interfering proteins are negligible relative to those from PDGFs (Figure 4B). In addition, the PDGF AA-

(23) (a) Hart, C. E.; Bailey, M.; Curtis, D. A.; Osborn, S.; Raines, E.; Ross, R.; Forstrom, J. W. Biochemistry 1990, 29, 166-172. (b) Lubinus, M.; Meier, K. E.; Smith, E. A.; Gause, K. C.; LeRoy, E. C.; Trojanowska, M. J. Biol. Chem. 1994, 269, 9822-9825. (c) Koempel, J. A.; Gibson, S. E.; O’Grady, K.; Toriumi, D. M. Int. J. Pediatr. Otorhinolaryngol. 1998, 46, 1-8. (d) Bentas, W.; Beecken, W.-D.; Glienke, W.; Binder, J.; Schuldes, H. Urol. Res. 2003, 30, 390-393.

(24) (a) Nolting, B.; Yu, J.-J.; Liu, G.-Y.; Cho, S.-J.; Kauzlarich, S.; Gervay-Hague, J. Langmuir 2003, 19, 6465-6473. (b) Verma, A.; Rotello, V. M. Chem. Commun. 2005, 303-312. (c) Ipe, B. I.; Yoosaf, K.; Thomas, K. G. J. Am. Chem. Soc. 2006, 128, 1907-1913. (d) Wang, G.; Zhang, J.; Murray, R. W. Anal. Chem. 2002, 74, 4320-4327. (e) Verma, A.; Nakade, H.; Simard, J. M.; Rotello, V. M. J. Am. Chem. Soc. 2004, 126, 10806-10807. (f) de la Fuente, J. M.; Penadés, S. Biochim. Biophys. Acta 2006, 1760, 636-651.
$\mathrm{L}_{\mathrm{AuND}} / \mathrm{Apt}-\mathrm{Q}_{\mathrm{AuNP}}$ system allowed the detection of PDGF AA at concentrations as low as $0.5 \mathrm{nM}$ in the presence of BSA at 10 $\mu \mathrm{M}$, that is, a 20000 -fold higher concentration (Figure S4, Supporting Information). This highly specific sensor displays high potential for detecting PDGFs in complex, real samples.

Competitive Assays of $\alpha$-Thrombin. To illustrate whether our new signaling strategy was applicable to the detection of other proteins, we tested another 27-nt DNA aptamer (Apt thrombin) that binds to Exosite II of $\alpha$-thrombin (an endoprotease protein that has many effects in the coagulation cascade). This aptamer has a unique structure, with G-quartet conjugated stem base pairs that allow binding to $\alpha$-thrombin. ${ }^{25}$ Again, we obtained a linear relationship (Figure S5, Supporting Information) between the photoluminescence intensity and the concentration of $\alpha$-thrombin added to a mixture of thrombin $-\mathrm{L}_{\mathrm{AuND}}(4.0 \mathrm{nM})$ and $\mathrm{Apt}_{\text {thrombin }}{ }^{-}$ $\mathrm{Q}_{\mathrm{AuNP}}(0.4 \mathrm{nM})$. The linear calibration curve for quantitation of $\alpha$-thrombin extended from 0.25 to $4.0 \mathrm{nM}$, with a correlation coefficient of 0.96 . The LOD for $\alpha$-thrombin at an $\mathrm{S} / \mathrm{N}$ ratio of 3 was $0.15 \mathrm{nM}$.

Competitive Assays of PDGF Receptor. The three isomeric PDGF molecules bind specifically, with different degrees, to two receptors: the PDGF $\alpha$ - and $\beta$-receptors. ${ }^{26}$ The dissociation constants $\left(K_{\mathrm{d}}\right)$ for the complexes of PDGF $\alpha$-receptor with PDGF $\mathrm{BB}, \mathrm{AB}$, and $\mathrm{AA}$ are $0.5,0.1$, and $0.2 \mathrm{nM}$, respectively..$^{26,27}$ Binding of the receptors to PDGF activates intracellular tyrosine kinase, leading to autophosphorylation of the cytoplasmic domain of the receptor as well as phosphorylation of other intracellular substrates..$^{27}$ The aptamer can inhibit the binding of PDGFs to their receptors and suppress the regulation of their receptors. ${ }^{13,28}$ Therefore, we believed that PDGF $\alpha$-receptor would bind to PDGF $\mathrm{AA}-\mathrm{L}_{\mathrm{AuND}}$ and inhibit their Apt- $\mathrm{Q}_{\mathrm{AuNP}}$-induced photoluminescence quenching (Scheme 1C). To test this hypothesis, we conducted a competitive assay using mixtures of $4 \mathrm{nM}$ PDGF AA- $\mathrm{L}_{\mathrm{AuND}}$ and $0.4 \mathrm{nM} \mathrm{Apt}-\mathrm{Q}_{\mathrm{AuNP}}$ to detect PDGF $\alpha$-receptor. As indicated in Figure S6 (Supporting Information), the photoluminescence of the mixture increased upon increasing the concentration of PDGF $\alpha$-receptor from 0 to $10 \mathrm{nM}$. The inset in Figure S6 displays a linear relationship between the photoluminescence intensity of the mixture at $520 \mathrm{~nm}$ and the PDGF $\alpha$-receptor concentration over the range $0.5-5.0 \mathrm{nM}$, with a correlation coefficient of 0.93 . On the basis of an $\mathrm{S} / \mathrm{N}$ ratio of 3 , we estimated the LOD for PDGF $\alpha$-receptor to be $0.25 \mathrm{nM}$.

Analyses of PDGFs in Biological Samples. To test the practicality of this assay, we conducted analyses of PDGFs in biological samples. Our first representative example was a serumfree conditioned cell medium (MEM) that had been collected from the human breast carcinoma HTB-26. It has been reported that

(25) (a) Bock, L. C.; Griffin, L. C.; Latham, J. A.; Vermaas, E. H.; Toole, J. J. Nature 1992, 355, 564-566. (b) Tasset, D. M.; Kubik, M. F.; Steiner, W. J. Mol. Biol. 1997, 272, 688-698.

(26) (a) Meyer-Ingold, W.; Eichner, W. Cell Biol. Int. 1995, 19, 389-398. (b) Hart, C. E.; Forstrom, J. W.; Kelly, J. D.; Seifert, R. A.; Smith, R. A.; Ross, R.; Murray, M. J.; Bowen-Pope, D. F. Science 1988, 240, 1529-1531. (c) Seifert, R. A.; van Koppen, A.; Bowen-Pope, D. F. J. Biol. Chem. 1993, 268, 4473-4480.

(27) (a) Bishayee, S.; Majumdar, S.; Scher, C. D.; Khan, S. Mol. Cell. Biol. 1988, 8, 3696-3702. (b) Keating, M. T.; Escobedo, J. A.; Williams, L. T. J. Biol. Chem. 1988, 263, 12805-12808.

(28) Floege, J.; Ostendorf, T.; Janssen, U.; Burg, M.; Radeke, H. H.; Vargeese, C.; Gill, S. C.; Green, L. S.; Janjić, N. Am. J. Pathol. 1999, 154, 169-179. 

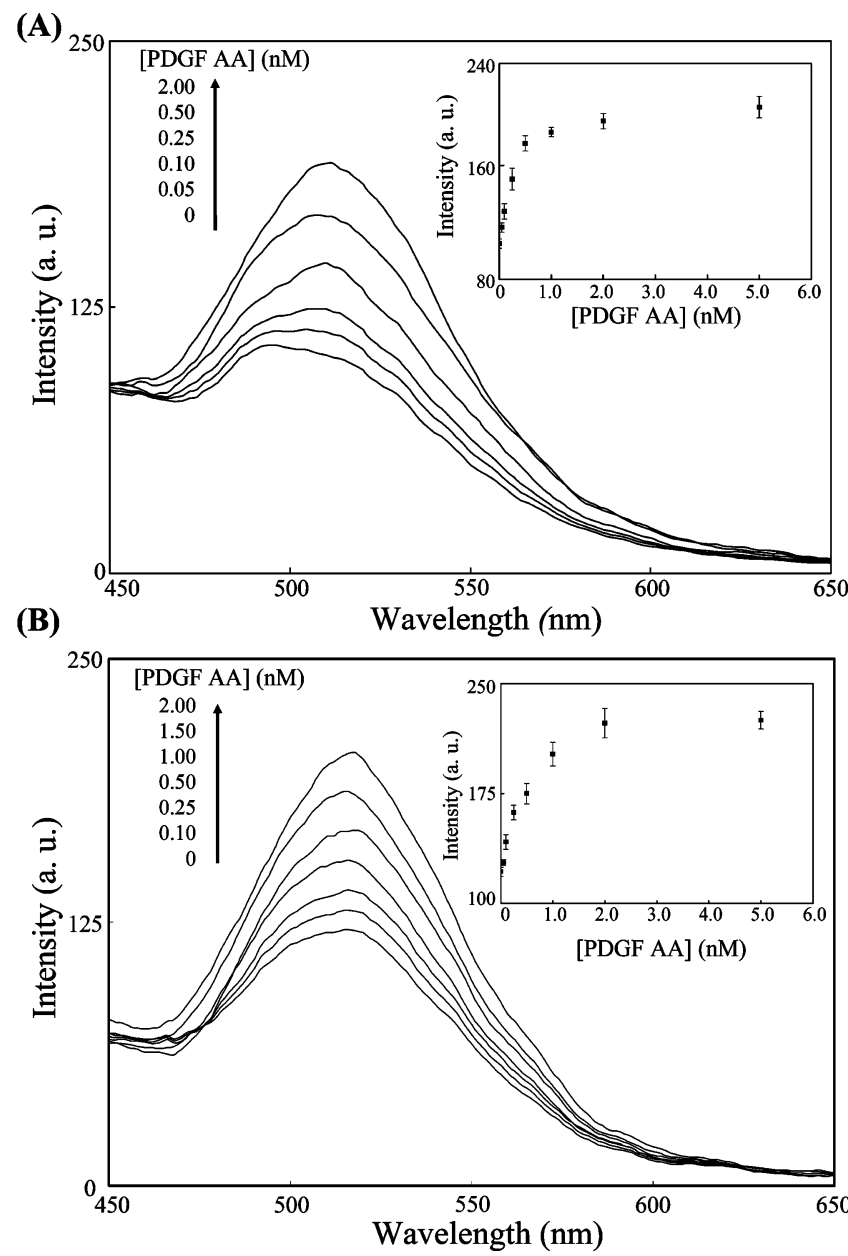

Figure 5. Validation of the use of PDGF $A A-L_{\text {Aund }} / A p t-Q_{A u N P}$ probes for the detection of PDGF AA $(0-5.0 \mathrm{nM})$ spiked in (A) cultured cell media and $(B)$ urine. The inset displays the increase in photoluminescence of PDGF AA- $\mathrm{L}_{\text {AuND }}$ upon increasing the concentration of PDGF AA. Error bars are standard deviation values across four repetitive experiments. Other conditions were the same as those described in Figure 3B.

PDGFs secrete in culture media at a level of $\sim 0.2 \mathrm{nM} .^{29}$ Unfortunately, an intense background fluorescence, contributed by some indigenous species in the cell medium, caused serious problems; the background fluorescence was over 10-fold greater than the photoluminescence intensity of PDGF AA- $\mathrm{L}_{\text {AuND }}(4 \mathrm{nM})$. To minimize interference, we developed an NP-assisted protein enrichment method to remove the matrix. Serum-free cell media (1 mL) diluted by a factor of 10, PDGF AA at concentrations ranging from 0 to $5.0 \mathrm{nM}$, and $\mathrm{Apt}-\mathrm{Q}_{\mathrm{AuNP}}(0.04 \mathrm{nM})$ in buffer (5 $\mathrm{mM}$ sodium phosphate, $200 \mathrm{mM} \mathrm{NaCl}$; $\mathrm{pH} 7.4$ ) were mixed at $25^{\circ} \mathrm{C}$ for $1 \mathrm{~h}$. Subsequently, the samples were centrifuged, and the supernatants were removed. Finally, the precipitates were resuspended in $100-\mu \mathrm{L}$ solutions $(\mathrm{pH} 7.4)$ of $5 \mathrm{mM}$ sodium phosphate, $100 \mathrm{mM} \mathrm{NaCl}$, and $4 \mathrm{nM}$ PDGF AA- $\mathrm{L}_{\text {Aund }}$ and left for another $1 \mathrm{~h}$. Figure $5 \mathrm{~A}$ displays photoluminescence spectra of the mixtures recorded at various concentrations of PDGF AA. These spectra indicate that the photoluminescence responses increased upon increasing the concentration of PDGF AA. The

(29) Bronzert, D. A.; Pantazis, P.; Antoniades, H. N.; Kasid, A.; Davidson, N.; Dickson, R. B.; Lippman, M. E. Proc. Natl. Acad. Sci. U.S.A. 1987, 84, 57635767.
LOD, at a S/N ratio of 3 , for PDGF AA spiked in HTB-26 cell media was $10 \mathrm{pM}$. We achieved a recovery of $96 \%$ for PDGF AA and determined the concentration of PDGFs in the collected cell media to be $0.18( \pm 0.04) \mathrm{nM}$, which is in good agreement with the reported value. ${ }^{29}$

We also utilized our sensor system to determine PDGFs in urine samples, because their levels can be indicative of certain diseases. For example, the concentrations of PDGF in urine samples from patients with myelofibrosis and essential thrombocythemia are $0.25( \pm 0.08)$ and $0.41( \pm 0.08) \mathrm{nM}$, respectively, both significantly higher than that from healthy people $[0.08$ $( \pm 0.01) \mathrm{nM}] .{ }^{30}$ Again, we applied the Apt-Q AunP-assisted PDGF $\mathrm{AA}$ enrichment method because of serious matrix interference in urine samples (Figure 5B). We achieved a recovery of $95 \%$ for PDGF AA and determined the concentration of PDGFs in the urine sample from a healthy man (31 years old) to be $0.10( \pm 0.02)$ $\mathrm{nM}$, which agrees well with the reported value. ${ }^{30} \mathrm{We}$ also try to detect PDGFs in human serum samples by the PDGF AA- $\mathrm{L}_{\mathrm{AuND}} /$ Apt- $\mathrm{Q}_{\text {AuNP }}$ system, but a high concentration of an interfering protein such as HSA in serum is $30-50 \mathrm{mg} / \mathrm{mL}$, which results in strong nonspecific binding with $\mathrm{Apt}-\mathrm{Q}_{\mathrm{AuNP}}$ to cause a failure in the performance of PDGF AA- $\mathrm{L}_{\mathrm{AuND}} / \mathrm{Apt}-\mathrm{Q}_{\mathrm{AuNP}}$ for detecting PDGFs. The thiol-PEG $\mathrm{CH}_{3} \mathrm{O}-\left(\mathrm{CH}_{2} \mathrm{CH}_{2} \mathrm{O}\right)_{n}-\mathrm{CH}_{2} \mathrm{CH}_{2} \mathrm{SH}$-modified or polymer blocked Apt- $\mathrm{Q}_{\text {AuNP, }}$ and controlling the aptamer density on $\mathrm{Q}_{\text {AuNP }}$ in our further work may reduce the nonspecific binding and allow detection of PDGFs in serum samples. ${ }^{31}$

\section{CONCLUSION}

To the best of our knowledge, this paper describes the first instance of the use of two differently sized AuNPs, acting separately as donor and acceptor, in homogeneous assays developed for the analysis of proteins. Our PDGF AA- $\mathrm{L}_{\mathrm{AuND}} / \mathrm{Apt}-$ $Q_{\text {AuNP-based molecular light-switching system allowed the analyses }}$ of PDGFs and PDGF $\alpha$-receptor in homogeneous solutions. This method takes advantage of the dramatic increase in the intensity of the turn-on photoluminescence signal of PDGF AA- $\mathrm{L}_{\mathrm{AuND}} / \mathrm{Apt}-$ $\mathrm{Q}_{\text {AuNP }}$ upon its binding with PDGFs. The PDGF AA- $\mathrm{L}_{\mathrm{AuND}} / \mathrm{Apt}-$ $\mathrm{Q}_{\text {AuNP }}$ system allowed the detection of PDGF AA at concentrations as low as $0.5 \mathrm{nM}$ in the presence of BSA at $10 \mu \mathrm{M}$. We have also demonstrated that the Apt- $\mathrm{Q}_{\text {AuNP }}$ are effective selectors for enriching PDGF AA from large-volume cell media and urine samples. This approach allows removal of most of the background fluorescence, leading to detection of PDGF AA at concentrations as low as $10 \mathrm{pM}$, although ELISA's PDGF kits can separately detect to picograms per milliliter of PDGF AA, $\mathrm{AB}$, and $\mathrm{BB} .{ }^{30}$ Our present method can detect total PDGFs in biological samples, such as cultured cell medium and urine samples. With its advantages of rapidity and specificity, this present approach holds great potential for use in protein analysis and cancer diagnosis.

\section{ACKNOWLEDGMENT}

This study was supported by the National Science Council of Taiwan under contracts NSC 95-2113-M-002-026-MY3 and NSC

(30) Gersuk, G. M.; Carmel, R.; Pattengale, P. K. Blood 1989, 74, 2330-2334. (31) (a) Carrigan, S. D.; Tabrizian, M. Langmuir 2005, 21, 12320-12326. (b) Feller, L. M.; Cerritelli, S.; Textor, M.; Hubbell, J. A.; Tosatti, S. G. P. Macromolecules 2005, 38, 10503-10510. (c) Bini, A.; Minunni, M.; Tombelli, S.; Centi, S.; Mascini, M. Anal. Chem. 2007, 79, 3016-3019. 
96-2627-M-002-014. C.-C. Huang acknowledges the PDF support from National Taiwan University.

\section{SUPPORTING INFORMATION AVAILABLE}

Photoluminescence intensities at $520 \mathrm{~nm}$ of $11-\mathrm{MUA}-\mathrm{L}_{\mathrm{AuND}}$ $(10 \mathrm{nM})$ prepared in (A) $10 \mathrm{mM}$ sodium phosphate $(\mathrm{pH} 3.0-11.0)$ and (B) $5 \mathrm{mM}$ sodium phosphate ( $\mathrm{pH} 7.4$ ) containing $0-1.5 \mathrm{M}$ $\mathrm{NaCl}$ (Figure S1). Photoluminescence spectra of 11-MUA- $\mathrm{L}_{\mathrm{AuND}}$ $(4 \mathrm{nM})$ in the presence of PDGF AA $(0-8.0 \mathrm{nM})$ (Figure S2). UV-vis absorption spectra of the Apt-Q $\mathrm{Q}_{\text {AuNP }}(0.6 \mathrm{nM})$ in $5 \mathrm{mM}$ phosphate solution ( $\mathrm{pH} 7.4$ ) containing $200 \mathrm{mM} \mathrm{NaCl}$ and 11MUA-L $\mathrm{L}_{\text {AuND }}(4.0 \mathrm{nM})$ at various concentration ratios of [PDGF
$\mathrm{AA}] /\left[11-\mathrm{MUA}-\mathrm{L}_{\mathrm{AuND}}\right]$ (Figure S3). Photoluminescence spectra of PDGF AA- $\mathrm{L}_{\mathrm{AuND}}(4.0 \mathrm{nM}), \mathrm{Apt}-\mathrm{Q}_{\mathrm{AuNP}}(0.4 \mathrm{nM})$, and PDGF AA $(0-2.5 \mathrm{nM})$ in the presence of $10 \mu \mathrm{M}$ BSA (Figure S4). Competitive binding assay for $\alpha$-thrombin $(0-25 \mathrm{nM})$ using the thrombin $-\mathrm{L}_{\mathrm{AuND}} / \mathrm{Apt}_{\text {thrombin }}-\mathrm{Q}_{\text {AuNP }}$ probe (Figure S5). Competitive binding assay for PDGF $\alpha$-receptor using the PDGF AA- $\mathrm{L}_{\mathrm{AuND}} /$ Apt $-Q_{\text {AuNP }}$ probe (Figure S6).

Received for review September 22, 2007. Accepted December 10, 2007.

AC701998F 